\title{
Zagrebačka strategija borbe protiv siromaštva i socijalne isključenosti za razdoblje od 2021. do 2025.
}

\author{
UDK: 364.65-058.34+058.64(,ZZagreb“)
}

doi: $10.3935 /$ rsp.v28i2.1852

Sve veća neizvjesnost i nesigurnost kombinirana s rizicima suvremenog doba i s očekivanim posljedicama uzrokovanim svjetskom pandemijom COVID-19 (u daljnjem tekstu: pandemija) te potresom koji je prouzročio velike materijalne štete, smanjenje državnog bruto društvenog proizvoda za $15 \%$ u drugome te $10 \%$ u trećem tromjesečju 2020. (Državni zavod za statistiku, 2020.a) s povećanjem stope nezaposlenosti, zahtijevalo je strateški i integrirani dokument na temelju kojeg Grad Zagreb želi olakšati položaj socijalno ugroženih građana Grada Zagreba i osigurati im bolju kvalitetu života. Stvaranje pretpostavki za ublažavanje posljedica koje nastaju ili će tek uslijediti zbog nepovoljnih svjetskih zbivanja te anticipirane krize prioritet je Zagrebačke strategije borbe protiv siromaštva i socijalne isključenosti za razdoblje od 2021. do 2025. (Službeni glasnik Grada Zagreba, 8/21) (u daljnjem tekstu: Zagrebačka strategija). Zagrebačka strategija je odgovor Gradske uprave, a koja je zadužena za kreiranje javnih politika, na novonastale krizne okolnosti radi što boljeg usmjeravanja budućeg djelovanja te suočavanja s predstojećim izazovima.

Prepoznavanjem potreba, novim mjerama i aktivnostima te praćenjem stanja siromaštva i socijalne isključenosti, u Gradu Zagrebu će se voditi osobita briga o ublažavanju i smanjenju rizika od siromaštva socijalno najugroženijih građana kako bi im se omogućio izlazak iz »kruga siromaštva « socijalnim ulaganjem i kvalitetnim socijal- nim uslugama te suradnjom svih uključenih dionika. Zagrebačka strategija proširuje obuhvat postojećih prava i usluga, ali kreira i nove kako bi s lokalne (regionalne) razine utjecala na kvalitetu života građana, osobito onih u povećanome riziku od siromaštva i socijalne isključenosti.

Zagrebačka strategija sastoji se od: Uvoda, Analize stanja, Analize prava socijalne skrbi koju osigurava Grad Zagreb, Gradski ured za socijalnu zaštitu i osobe s invaliditetom te Strateških ciljeva i mjera. Usto, sadržava i 3 priloga - Popis međunarodnih, nacionalnih i gradskih strateških dokumenata na kojima se temelji Strategija, Analiza prava iz nadležnosti Centra za socijalnu skrb Zagreb u razdoblju od 2015. do 2020. i Prikaz rezultata pilot- istraživanja socioekonomskog statusa i kvalitete života nezaposlenih osoba u Gradu Zagrebu tijekom pandemije COVID-19 i nakon potresa što ih je proveo Gradski ured za socijalnu zaštitu i osobe s invaliditetom u rujnu 2020.

Zagrebačka strategija usvojena je na 40. sjednici Gradske skupštine Grada Zagreba 16. ožujka 2021. To je prvi strateški dokument koji tematizira borbu protiv siromaštva i socijalne isključenosti na lokalnoj razini u Republici Hrvatskoj.

Stručni nositelj izrade Zagrebačke strategije je Gradski ured za socijalnu zaštitu i osobe $s$ invaliditetom u suradnji s Povjerenstvom za izradu i praćenje Zagrebačke strategije borbe protiv siromaštva i socijalne isključenosti za razdoblje od 2021. do 2025. 
koje je Zaključkom imenovao gradonačelnik Grada Zagreba (Službeni glasnik Grada Zagreba, 25/20) (u daljnjem tekstu: Povjerenstvo). U navedeno Povjerenstvo imenovani su stručnjakinje/ci iz gradskih upravnih tijela, organizacija civilnog društva te akademske zajednice koji se u svome profesionalnom životu bave pitanjima siromaštva i socijalne isključenosti. Nacrt Zagrebačke strategije je prije usvajanja bio predmetom savjetovanja s javnošću o nacrtima općih akata čije donošenje ili izmjene utječu na interese građana.

\section{UVOD}

Teme siromaštva i socijalne isključenosti u strateškim dokumentima Republike Hrvatske prepoznate su još 2002. donošenjem prvog Programa borbe protiv siromaštva i socijalne isključenosti (Vlada Republike Hrvatske, 2002.) te u ožujku 2014. Strategije borbe protiv siromaštva i socijalne isključenosti u Republici Hrvatskoj (2014. -2020.) (Vlada Republike Hrvatske, 2014.). U tijeku je izrada nove nacionalne strategije.

Na europskoj razini u studenom 2017. godine donesen je strateški dokument naziva »Europski stup socijalnih prava k koji, između ostaloga, naglašava »da svatko tko nema dovoljno sredstava ima pravo na adekvatan minimalni dohodak koji osigurava dostojanstven život« (Europska komisija, 2017.).

Lokalnim modelom socijalne zaštite koji je usmjeren na socijalno ugrožene građane, Grad Zagreb želi ostvariti dva cilja - zadovoljenje egzistencijalnih potreba i bolju kvalitetu života nadopunom državnog sustava socijalne skrbi. Komplementarnim mjerama i kombiniranim modelom socijalne politike kao nadogradnje državnog sustava socijalne skrbi te širokim partnerstvima s lokalnim dionicima, Grad Zagreb kao jedinica područne (regionalne) samouprave pokušava odgovoriti na rastuće potrebe građana. $\mathrm{Na}$ projektu »Sinergijski socijalni sustav« koji se provodio u okviru Programa Unije za zapošljavanje i socijalnu solidarnost - PROGRESS (2007. - 2013.), izrađeno je Izvješće o strukturi naknada, izdacima i korisnicima programa socijalne zaštite u Republici Hrvatskoj (2016.) (Šućur i sur., 2016.). Izvješće navodi da gradovi u prosjeku imaju veći broj socijalnih programa/naknada nego općine (7,9 u odnosu na 4,8), dok je u Gradu Zagrebu ukupni broj naknada znatno veći od prosjeka za gradove ili veće gradove, točnije 29 programa/naknada. Grad Zagreb prednjači po broju programa za umirovljenike i osobe starije životne dobi te za osobe s invaliditetom. Izvješće se zaključuje podatkom da Grad Zagreb izdvaja najviše sredstava za socijalnu zaštitu po glavi stanovnika te da više od $56 \%$ troškova za socijalnu zaštitu svih jedinica lokalne i područne (regionalne) samouprave čine troškovi socijalnih programa Grada Zagreba (Šućur i sur., 2016.). Istovrsna analiza u članku »Decentralizacija socijalne skrbi i socijalne nejednakosti: slučaj Hrvatske« pokazuje da građani Grada Zagreba u usporedbi s ostalim gradovima iz uzorka ostvaruju najveću razinu socijalnih prava, a posebice se mogu istaknuti umirovljenici, osobe s invaliditetom te programi usmjereni na djecu i obitelj (Babić, 2017.: 45).

Člankom 117. Zakona o socijalnoj skrbi (Narodne novine, 157/13, 152/14, 99/15, $52 / 16,16 / 17,130 / 17,98 / 19,64 / 20,138 / 20$ Uredba) (u daljnjem tekstu: Zakon) jedinicama lokalne i područne (regionalne) samouprave dana je mogućnost osiguranja sredstava za ostvarivanje novčanih naknada i socijalnih usluga stanovnicima na njihovu području u većem opsegu nego što je utvrđeno Zakonom, a kako je propisano njihovim općim aktom, imaju li u proračunu osigurana sredstva. Tako je zakonski omogućen pluralizam socijalnih programa na lokalnoj i regionalnoj razini te nadopuna funkcija lokalnih socijalnih politika.

Odlukom o socijalnoj skrbi (Službeni glasnik Grada Zagreba, 26/14, 19/15, 06/16,16/16, 23/16, 04/19, 6/20, 17/20, Pročišćeni tekst, 22/20) (u daljnjem tekstu: 
Odluka) utvrđuju se prava koja osigurava Grad Zagreb te uvjeti i način njihova ostvarivanja, korisnici socijalne skrbi i postupak za ostvarivanje tih prava.

Grad Zagreb dosadašnjim strateškim dokumentima prepoznaje siromaštvo kao jedan od rastućih rizika, no prepoznaje potrebu za posebnim dokumentom koji bi se usredotočio samo na segment borbe protiv siromaštva i socijalne isključenosti.

U uvodnome dijelu Zagrebačke strategije definiraju se temeljni pojmovi, npr. siromaštvo, socijalna isključenost, novo siromaštvo, dječje siromaštvo, energetsko siromaštvo te siromaštvo zaposlenih. Osim tog pojmovlja, definira se i stopa rizika od siromaštva, osobe i riziku od siromaštva te stopa rizika od siromaštva prema najčešćem statusu u aktivnosti.

\section{ANALIZA STANJA}

Prosječna stopa rizika od siromaštva u zemljama Europske unije u 2018. bila je 16,8\% (Eurostat, 2020.). Sukladno Pokazateljima siromaštva i socijalne isključenosti u Republici Hrvatskoj za 2019. (Državni zavod za statistiku, 2020.b), stopa rizika od siromaštva se s $19,3 \%$ u 2018. smanjila na $18,3 \%$. Prag rizika od siromaštva iskazan u kunama za jednočlano kućanstvo iznosio je 32520 , a za kućanstvo s dvije odrasle osobe i s dvoje djece iznosio je 68292 kuna godišnje.

U Republici Hrvatskoj u 2018. je u riziku od siromaštva ili socijalne isključenosti bilo $24,8 \%$ osoba od ukupnog stanovništva, dok dostupni podaci za 2019. pokazuju da se broj takvih osoba u općoj populaciji smanjio na $23,3 \%$. U istoj godini, primjerice, Europska unija bilježi stopu od $21 \%$.

U 2019. u najvišem riziku od siromaštva su osobe starije od 65. godine, a iznosi $30,1 \%$. U toj skupini, u najvećem riziku od $33,6 \%$ su žene.

$\mathrm{U}$ istoj godini, stopa rizika od siromaštva prema najčešćem statusu po aktivnosti najviša je za nezaposlene osobe te iznosi $45,3 \%$. U kategoriji kućanstava s uzdržavanom djecom najviše stope rizika od siromaštva zabilježene su u kućanstvima koja čini jedan roditelj s uzdržavanom djecom i za koje je stopa $33,8 \%$, tj. jednoroditeljske obitelji te u višečlanim obiteljima, tj. kućanstvima s dvije odrasle osobe s troje ili više djece za koje stopa rizika od siromaštva iznosi $25,6 \%$. Stopa rizika dječjeg siromaštva (osobe od 0 do 17 godina) tijekom godina je u 2010. bila 19,4\%, 21,2\% u 2014., $19,7 \%$ u 2018. te $17,1 \%$ u 2019. Prema dostupnim podacima za 2019., postoje različite stope rizika od siromaštva pa stopa rizika za djecu od 6 do 11 godine iznosi 17,4\%, a za djecu od 12 do 17 godina 20\% (Državni zavod za statistiku, 2020.b).

U povećanom riziku od siromaštva su i osobe s invaliditetom i blokirani građani za koje se ne vode službeni podaci.

Glede nezaposlenosti, podaci Hrvatskog zavoda za zapošljavanje pokazuju da zbog utjecaja pandemije broj nezaposlenih počinje rasti u 2020. te je viši za 24,25\% u odnosu na prijašnju godinu, a stopa registrirane nezaposlenosti iznosi 9,3\% (Hrvatski zavod za zapošljavanje, 2020.).

\section{Grad Zagreb}

Stopa registrirane nezaposlenosti u Gradu Zagrebu za studeni 2020. iznosi 4,6\% (Grad Zagreb, 2020.). U prosincu 2020. registrirano je 20287 nezaposlenih osoba, dok ih je u istome razdoblju 2019. godine bilo 14 964. Stoga je u 2020. u Gradu Zagrebu došlo do povećanja broja registriranih nezaposlenih osoba za 35,57\%, odnosno za 5323 osobe u odnosu na isto razdoblje 2019. godine zbog pandemije.

$\mathrm{U}$ istraživanju »Mapiranje i procjena geografske raspodjele rizika od siromaštva i socijalne isključenosti za mala područja Republike Hrvatske« (Državni zavod za statistiku, 2016.) su prvi put predstavljene procjene podataka po županijama. Procije- 
njena stopa rizika od siromaštva u Gradu Zagrebu u 2016. iznosila je 9,8\% po dohodovnoj metodi te je najniža u državi. No, treba naglasiti da se stope rizika od siromaštva mjere samo na državnoj razini.

U sklopu Zagrebačke strategije izrađena je i analiza prava na temelju Odluke o socijalnoj skrbi Grada Zagreba (Službeni glasnik Grada Zagreba, 26/14, 19/15, 06/16,16/16, 23/16, 04/19, 6/20, 17/20, Pročišćeni tekst, 22/20) za razdoblje od 2015. do 2020. Prava obuhvaćaju novčanu ротоć (umirovljenicima; za plaćanje premije dopunskog zdravstvenog osiguranja korisnicima novčane pomoći umirovljenicima; korisnicima doplatka za pomoć i njegu i korisnicima osobne invalidnine; osobama kojima je priznato pravo na status roditelja njegovatelja ili status njegovatelja; za osobne potrebe (džeparac) korisnicima doma za starije osobe; naknada za troškove stanovanja, pravo na troškove ogrjeva), pomoći u naravi (djeci u mliječnoj hrani; u obiteljskim paketima; ljetovanje; prehrana u pučkoj kuhinji; pravo na besplatnu godišnju pokaznu kartu ZET-a), privremeni smještaj (pružanje usluge stanovanja, prehrane, brige o zdravlju i njege, usluge socijalnog rada i pomoći pri socijalnom uključivanju, ovisno o utvrđenim potrebama i mogućnostima korisnika) te druge oblike pomoći (pomoć u kući, savjetovanje i pomaganje, podmirenje pogrebnih troškova). Analiza broja korisnika prava ukazuje na trend smanjenja broja korisnika za pojedina prava zbog tadašnjih povoljnijih gospodarskih kretanja. Porast broja korisnika zamjetan je kod triju prava socijalne skrbi Grada Zagreba, a to su pravo na novčanu pomoć korisnicima doplatka za pomoć i njegu i korisnicima osobne invalidnine; pravo na status roditelja njegovatelja ili status njegovatelja te pravo na pomoć u kući.

Analiza prava iz nadležnosti Centra za socijalnu skrb Zagreb u razdoblju od 2015. do 2020. ukazuje na trend opadanja korištenja prava (zajamčena minimalna naknada, jednokratna naknada, naknade u vezi s obra- zovanjem, naknada do zaposlenja), dok prava po osnovi invaliditeta rastu (doplatak za pomoć i njegu, osobna invalidnina, status roditelja njegovatelja ili njegovatelja). Važno je napomenuti da ovaj trend ukazuje na poboljšana ekonomska kretanja u tom razdoblju.

Tijekom pripreme i izrade Zagrebačke strategije, provedeno je pilot-istraživanje socioekonomskog statusa i kvalitete života nezaposlenih osoba u Gradu Zagrebu. Gradski ured za socijalnu zaštitu i osobe s invaliditetom proveo je istraživanje tijekom rujna 2020. na uzorku od 118 nezaposlenih osoba s područja Grada Zagreba online anketom. Najvažniji rezultati su: 77,2\% sudionika percipiralo je da im je materijalno stanje pogoršano pandemijom, 22,9\% ih je izgubilo posao upravo zbog posljedica pandemije, a 58,5\% ih je svoje materijalno stanje procijenilo lošim. Najveći dio osobnih primanja sudionici troše na hranu i režije, zatim na stanarinu i kredite, a najmanji dio na odjeću i obuću, izvannastavne aktivnosti i slobodno vrijeme. Za vlastitu sigurnost $u$ budućnosti je zabrinuto $72,03 \%$ ispitanika.

\section{STRATEŠKI CILJEVI I MJERE}

Cilj Zagrebačke strategije borbe protiv siromaštva i socijalne isključenosti za razdoblje od 2021. do 2025. godine je prevencija i smanjenje rizika od siromaštva i socijalne isključenosti na području Grada Zagreba.

Kako bi se ostvario zadani strateški cilj, imenovani su sljedeći podciljevi:

1. razvijanje dinamičnog modela socijalnih prava kao ciljanih, obuhvatnih, adekvatnih te nadopunjavajućih radi zadovoljenja egzistencijalnih potreba građana Grada Zagreba i uključivanja u zajednicu

2. osiguranje kvalitete, dostupnosti i raznovrsnosti socijalnih usluga te socijalno ulaganje koje će omogućiti punu participaciju građana Grada Zagreba u društvu 
3. sustavna i sveobuhvatna istraživanja o kvaliteti života, dobrobiti i socioekonomskom statusu osoba koje su u najvećem riziku od siromaštva i socijalne isključenosti u Gradu Zagrebu radi uvida u potrebe građana

4. viša razina suradnje ključnih dionika u procesu unaprjeđenja modela socijalne zaštite te senzibilizacije javnosti za problematiku siromaštva i socijalne isključenosti.

Unutar svakoga strateškog podcilja navedene su mjere, nositelji te sunositelji aktivnosti, rokovi, pokazatelji uspješnosti i potrebna financijska sredstva.

Ad.1. Razvijanje dinamičnog modela socijalnih prava kao ciljanih, obuhvatnih, adekvatnih te nadopunjavajućih radi zadovoljenja egzistencijalnih potreba građana Grada Zagreba i uključivanja u zajednicu

Osnova za socijalno uključivanje pojedinca je zadovoljenje osnovnih egzistencijalnih potreba, i pojedinaca i obitelji. Razvijanjem modela socijalne skrbi na temelju utvrđenih korisnikovih potreba i aktiviranjem raspoloživih resursa u zajednici, Grad Zagreb nastoji preventivno djelovati na posljedice gospodarske krize prouzročene pandemijom COVID-19 te na smanjenje siromaštva u Gradu Zagrebu.

Mjere su:

1. redovito osiguravanje prava socijalne skrbi sukladno Odluci o socijalnoj skrbi Grada Zagreba

2. povećanje cenzusa za novčanu pomoć umirovljenicima radi povećanja dostupnosti prava i kvalitete života

3. proširenje obuhvata korisničkih prava na naknadu za troškove stanovanja

4. unaprjeđenje podrške za korisnike socijalne skrbi - samce

5. osiguravanje pomoći u namirnicama i u osnovnim higijenskim potrepštinama osobama u riziku od siromaštva i socijalne isključenosti

6. unaprjeđenje podrške za korisnike smještene u skloništa za žrtve obiteljskog nasilja na području Grada Zagreba

7. osiguravanje energetskih paketa za korisnike prava na naknadu za troškove stanovanja

8. proširenje obuhvata korisnika prava na obiteljske pakete

9. osiguravanje pomoći i podrške građanima u kriznim situacijama.

Ad.2. Osiguranje kvalitete, dostupnosti i raznovrsnosti socijalnih usluga te socijalno ulaganje koje će omogućiti punu participaciju građana Grada Zagreba u društvu

Osnaživanje i integracija pojedinaca i obitelji u život zajednice ključne su aktivnosti za uspostavu pravedne i socijalno osviještene zajednice. Grad Zagreb želi unaprijediti i proširiti mrežu prilagođenih i dostupnih socijalnih usluga koje će omogućiti korisnicima da uz podršku razvijaju svoje potencijale i da ravnopravno sudjeluju u društvenom životu zajednice.

Mjere su:

1. uključivanje što većeg broja djece u programe predškolskog odgoja i obrazovanja u dječjim vrtićima Grada Zagreba u cilju smanjenja rizika od siromaštva i socijalne isključenosti

2. poticanje učinkovitog i ravnopravnog sudjelovanja djece u odgojno-obrazovnome procesu

3. osiguravanje dostupnosti i kvalitete obrazovanja stipendiranjem različitih korisničkih kategorija

4. provedba programa zdravstvenih nadstandarda u promicanju vrijednosti zdravlja, edukacije, prevencije, rane dijagnostike te liječenja

5. osiguravanje uvjeta za provedbu mjera iz spektra usluga podrške i obiteljske asistencije za jednoroditeljske obitelji 
6. poticanje volontera na rad s osobama u povećanom riziku

7. organiziranje slobodnih aktivnosti za djecu i odrasle u riziku od siromaštva i socijalne isključenosti

8. senzibilizacija mladih za društveno-korisno učenje radi smanjenja siromaštva i socijalne isključenosti na području Grada Zagreba

9. jačanja financijske pismenosti osoba koje su u riziku od siromaštva i socijalne isključenosti

10. zbrinjavanje i integracija beskućnika pomoću usluge privremenog smještaja

11. prevencija beskućništva poticanjem osnivanja stambenih zajednica za mlade koji izlaze iz alternativne skrbi

12. stručna podrška korisnicima prava socijalne skrbi Grada Zagreba

13. poticanje motivacije $\mathrm{i}$ interesa teže zapošljivih nezaposlenih osoba na uključivanje u besplatne programe stjecanja osnovnoškolskog obrazovanja i prvog zanimanja te na uključivanje u obrazovanje za deficitarna zanimanja radi stjecanja novog zanimanja

14. poticanje poslodavaca da zapošljavaju teže zapošljive osobe kojima prijeti siromaštvo i socijalna isključenost

15. osiguravanje potpora za razvoj društvenog poduzetništva

16. javne radne aktivnosti za nezaposlene hrvatske branitelje i nezaposlene građane Zagreba.

Ad.3. Sustavna i sveobuhvatna istraživanja o kvaliteti života, dobrobiti i socioekonomskom statusu osoba koje su u najvećem riziku od siromaštva i socijalne isključenosti u Gradu Zagrebu radi uvida u potrebe građana

Istraživanje potreba građana Zagreba pomoću kvantitativnih i kvalitativnih metoda te s primjerenim instrumentima, Grad se želi upoznati s potrebama i teškoćama skupina koje su u visokom riziku od siromaštva. Na temelju rezultata istraživanja, Grad Zagreb će djelovati izravno, s mjerama i aktivnostima koje su usmjerene na ranjive skupine te neizravno, s diseminiranim rezultatima kroz publikacije te stručne i znanstvene analize iz kojih će proizaći praktične implikacije istraživanja koje mogu poslužiti kao primjeri dobre prakse. Osim toga, prezentacijom rezultata istraživanja nastojat će se senzibilizirati šira javnost te motivirati na djelovanje prema ranjivim društvenim skupinama.

Mjere su:

1. sustavna provedba istraživanja među skupinama koje su u riziku od siromaštva i socijalne isključenosti te među stručnjacima koji se bave siromaštvom i socijalnom isključenošću

2. redovito praćenje pokazatelja siromaštva i socijalne isključenosti na području Grada Zagreba.

Ad.4. Viša razina suradnje ključnih dionika u procesu unaprjeđenja modela socijalne zaštite te senzibilizacije javnosti za problematiku siromaštva i socijalne isključenosti

Suradnja i komunikacija dionika u sustavu socijalne skrbi jedan je od važnijih čimbenika u unaprjeđenju modela socijalne zaštite jer će se posebna pažnja posvetiti prepoznavanju i povezivanju unutar sustava te razvijanju partnerstva s dionicima drugih sustava radi pravovremena i učinkovita rješavanja konkretnih situacija. Cilj je uravnotežen sustav odgovornosti nositelja određenih aktivnosti kako bi se osiguralo učinkovito upravljanje socijalnim rizicima i unaprijedila socijalna dobrobit pojedinaca. Senzibiliziranjem šire javnosti za problematiku siromaštva se, osim pravodobna pružanja informacija o dostupnosti prava i usluga, potiče solidarnost s najugroženijim skupinama te se osnažuje kohezija zajednice. 


\section{Mjere su:}

1. unaprjeđenje međuresorne suradnje $u$ području borbe protiv siromaštva i socijalne isključenosti

2. unaprjeđenje suradnje i partnerstva na provedbi projekata s organizacijama civilnog društva u području siromaštva $i$ socijalne isključenosti

3. senzibiliziranje i informiranje javnosti za problematiku siromaštva i socijalne isključenosti.

U završnim odrednicama Zagrebačke strategije određeno je da će praćenje provedbe i koordinacije nadzirati Povjerenstvo za izradu i praćenje provedbe Zagrebačke strategije borbe protiv siromaštva i socijalne isključenosti za razdoblje od 2021. do 2025. Gradonačelnik Grada Zagreba će na prijedlog Gradskog ureda za socijalnu zaštitu i osobe s invaliditetom u suradnji s drugim nadležnim gradskim upravnim tijelima i Povjerenstvom, za svaku godinu, do kraja veljače tekuće godine, donositi godišnje planove provedbe Zagrebačke strategije. Provoditelji mjera Zagrebačke strategije će Gradskomu uredu za socijalnu zaštitu i osobe s invaliditetom svake godine do 15. veljače dostavljati izvješća o provedbi mjera i aktivnosti iz svoje nadležnosti za prethodnu godinu, a gradonačelnik Grada Zagreba će izvijestiti Gradsku skupštinu Grada Zagreba o provedbi mjera i aktivnosti iz Zagrebačke strategije.

\section{LITERATURA}

Babić, Z. (2018). Decentralizacija socijalne skrbi $i$ socijalne nejednakosti: slučaj Hrvatske. Revija za socijalnu politiku, 25(1), 25-47. https://doi. org/10.3935/rsp.v25i1.1458

Državni zavod za statistiku. (2016). Mapiranje i procjena geografske raspodjele rizika od siromaštva i socijalne isključenost iza mala područja $R H$. Dostupno na https://www.dzs.hr/hrv/important/ presscorner/Mapiranje\%20i\%20procjena\%20 geografske $\% 20$ raspodjele $\% 20$ rizika $\% 20$ od $\% 20$ siromastva\%20i\%20socijalne\%20iskljucenosti\%20za\%20mala\%20podrucja\%20Republike\%20Hrvatske.pdf
Državni zavod za statistiku. (2020a). Prva procjena tromjesečnog bruto domaćeg proizvoda za četvrto tromjesečje 2020. Dostupno na https://www.dzs.hr/Hrv_Eng/publication/2020/12-01-01_04_2020.htm

Državni zavod za statistiku. (2020b). Pokazatelji siromaštva i socijalne isključenosti u 2019. Dostupno na https://bit.ly/34Mgzbi

Europska komisija. (2017). Europski stup socijalnih prava. Dostupno na https://ec.europa. eu/info/strategy/priorities-2019-2024/economy-works-people/jobs-growth-and-investment/european-pillar-social-rights_en

Eurostat. (2020). Statistički podaci o dohodovnom siromaštvu. Dostupno na https://ec.europa.eu/ eurostat/statistics-explained/index.php?title=Income_poverty_statistics/hr

Grad Zagreb.(2020).Zaposlenost i nezaposlenost. Dostupno na https://www.zagreb.hr/userdocsimages/ arhiva/statistika/2020/zaposleni\%202020/Zaposleni\%20XI.\%202020\%20-\%20web.pdf

Hrvatski zavod za zapošljavanje. (2020). Statistika. Dostupno na https://statistika.hzz.hr/Statistika. aspx?tipIzvjestaja $=1$

Odluka o socijalnoj skrbi. Službeni glasnik Grada Zagreba, br. 26/2014, 19/2015,06/2016, 16/2016, 23/2016, 04/2019, 6/2020, 17/2020 Pročišćeni tekst, 22/2020).

Šućur, Z., Babić, Z., Urban, I., \& Baran, J. (2016). Struktura naknada, izdaci i korisnici programa socijalne zaštite u Republici Hrvatskoj. Zagreb: Ministarstvo socijalne politike i mladih.

Vlada Republike Hrvatske. (2002). Program borbe protiv siromaštva i socijalne isključenosti. Dostupno na https://vlada.gov.hr/UserDocsImages/2016/Sjednice/Arhiva/5.\%20-\%204.pdf

Vlada Republike Hrvatske. (2014). Strategija borbe protiv siromaštva $i$ socijalne isključenosti $u$ Republici Hrvatskoj (2014.-2020.). Dostupno na https://bit.ly/3oQH8E6

Zagrebačka strategija borbe protiv siromaštva i socijalne isključenosti za razdoblje od 2021. do 2025. godine. Službeni glasnik Grada Zagreba, br. $8 / 2021$.

Zakon o socijalnoj skrbi. Narodne novine, br.157/2013, 152/2014, 99/2015, 52/2016, 16/2017, 130/2017, 98/2019, 64/2020, 138/2020 Uredba).

Pripremile:

dr.sc. Romana Galić, univ. spec. act. soc. mr. sc. Iva Prpić, dipl. soc. radnica Jasminka Đurek Pavlina, univ. spec. admin. urb. 